\title{
First characterization of a taxonomically well-resolved trophic network composed by host plants and gall midges (Diptera: Cecidomyiidae) in the Neotropical region
}

\author{
Walter Santos de Araújo ${ }^{1} \&$ Valéria Cid Maia ${ }^{2}$ \\ 1 Universidade Estadual de Montes Claros (UNIMONTES), Centro de Ciências Biológicas e da Saúde (CCBS), Departamento de Biologia Geral. \\ Montes Claros, MG, Brasil. ORCID: http://orcid.org/0000-0003-0157-6151. E-mail: walterbioaraujo@gmail.com (corresponding author) \\ ${ }^{2}$ Universidade Federal do Rio de Janeiro (UFRJ), Museu Nacional (MN), Departamento de Entomologia, Laboratório de Diptera. \\ Rio de Janeiro, RJ, Brasil. ORCID: http://orcid.org/0000-0001-9396-5618. E-mail: maiavcid@acd.ufrj.br
}

\begin{abstract}
In the present study we described the structure of a trophic network composed by gall-midge species (Diptera: (ecidomyiidae) and their host plants in the Restinga of Barra de Maricá (Maricá, Rio de Janeiro, Brazil). Species data were retrieved from literature and different topological descriptors (links per species, connectance, and modularity of interactions) were used. All gall-midge species were monophages, with connectance of $2.8 \%$ of the 2,016 possible interactions. The network of host plants and gall midges had low number of links per species and high modularity, which indicates high specificity and specialization of plant-galling interactions in the area. This is the first characterization of a trophic network with good taxonomic resolution for the Neotropical gall midges.
\end{abstract}

Keywords. Atlantic Forest; Cecidomyiidae; Diptera; Plant-galling interactions; Specificity.

\section{INTRODUCTION}

Cecidomyiidae (Diptera) is the most diverse group of gall-inducing insects in the world, with more than 6,500 described species (Gagné \& Jaschhof, 2017). Nevertheless, the Neotropical fauna comprises only about $8 \%$ of the known species, a very low percentage, considering that in this region there are some megadiverse countries (Fernandes \& Santos, 2014). The Brazilian fauna includes about $50 \%$ of the described Neotropical species (Gagné, 1994; Gagné \& Jaschhof, 2017), most of them from the Atlantic Forest. This situation reflects the scarcity of taxonomical studies about gall midges (Araújo et al., 2019a), which makes it difficult to understand biological and ecological processes involving these insects and their host plants.

In the present study, we describe for the first time a taxonomically well-resolved network composed by host plants and gall midges at the Restinga of Barra de Maricá, municipality of Maricá, State of Rio de Janeiro, Southeastern Brazil. Restinga or coastal shrub zone is one of the most endangered vegetal physiognomy of the Brazilian Atlantic Forest due to anthropic action (Santos et al., 2017). For explore the network structure we used different topological descriptors (links per species, connectance, modularity, and robustness of interactions) commonly indicated to describe the architecture of binary bipartite networks (review in Dormann et al., 2009).

\section{MATERIAL AND METHODS}

\section{Data compilation}

Maia studied the Restinga of Barra de Maricá for several years, from 1992 to 2011, during which this author and collaborators recorded a great amount of insect galls and their host plants, and described many gall midge species. In the present study, we compiled these data and arranged them in a database containing the gall-midge species and their host plants in order to building a list of plant-galling interactions (Table 1). All data used were previously published (Appendix 1). Only plants and gall midges identified at specific level were used in the compilation. All botanical names were updated using the database Flora do Brasil (2020) and nomenclature of gall midges was verified using Gagné \& Jaschhof (2017). 
Table 1. Checklist of host plants and gall midges recorded in the Restinga of Barra de Maricá (Maricá, RJ, Brazil).

\begin{tabular}{|c|c|}
\hline Host species & Gall midge species \\
\hline Borreria verticillata (L.) G. Mey. & Asphondylia borreriae Rübsaamen, 1905 \\
\hline Byrsonima sericea DC. & Bruggmanniella byrsonimae (Maia \& Couri, 1992) \\
\hline Byrsonima sericea DC. & Dasineura byrsonimae Maia, 2010 \\
\hline Clusia fluminensis Planch. \& Triana & Parazalepidota clusiae Maia, 2001 \\
\hline Clusia lanceolata Cambess. & Clusiamyia nitida Maia, 1996 \\
\hline Couepia ovalifolia (Schott) Benth. ex Hook.f. & Dasineura couepiae Maia, 2001 \\
\hline Couepia ovalifolia (Schott) Benth. ex Hook.f. & Lopesia marginalis Maia, 2001 \\
\hline Dalbergia ecastaphyllum (L.) Taub. & Lopesia grandis Maia, 2001 \\
\hline Erythroxylum ovalifolium Peyr. & Dasineura ovalifoliae Maia \& Fernandes, 2011 \\
\hline Erythroxylum ovalifolium Peyr. & Lopesia erythroxyli Rodrigues \& Maia, 2010 \\
\hline Eugenia astringens Cambess. & Dasineura globosa Maia, 1995 \\
\hline Eugenia astringens Cambess. & Dasineura marginalis Maia, 2005 \\
\hline Eugenia astringens Cambess. & Stephomyia rotundifoliorum Maia, 1993 \\
\hline Eugenia copacabanensis Kiaersk. & Stephomyia espiralis Maia, 1993 \\
\hline Eugenia copacabanensis Kiaersk. & Stephomyia tetralobae Maia, 1993 \\
\hline Eugenia uniflora $\mathrm{L}$. & Clinodiplosis profusa Maia, 2001 \\
\hline Eugenia uniflora $\mathrm{L}$. & Eugeniamyia triangularis Maia, 2011 \\
\hline Eugenia uniflora $\mathrm{L}$. & Neolasioptera eugeniae Maia, 1993 \\
\hline Fridericia conjugata (Vell.) L.G. Lohmann & Arrabiadaeamyia serrata Maia, 2001 \\
\hline Guapira opposita (Vell.) Reitz & Bruggmannia acaudata Maia, 2004 \\
\hline Guapira opposita (Vell.) Reitz & Bruggmannia elongata Maia \& Couri, 1993 \\
\hline Guapira opposita (Vell.) Reitz & Bruggmannia monteiroi Maia \& Couri, 1993 \\
\hline Guapira opposita (Vell.) Reitz & Bruggmannia robusta Maia \& Couri, 1993 \\
\hline Guapira opposita (Vell.) Reitz & Pisphondylia brasiliensis Couri \& Maia, 1992 \\
\hline Guapira opposita (Vell.) Reitz & Proasphondylia formosa Maia, 1993 \\
\hline Guapira opposita (Vell.) Reitz & Proasphondylia guapirae Maia, 1993 \\
\hline Heteropterys nitida (Lam.) DC. & Clinodiplosis floricola Novo-Guedes \& Maia, 2008 \\
\hline Hylocereus setaceus (Salm-Dyck) R.Bauer & Neolasioptera cerei (Rübsaamen, 1905) \\
\hline Jacquemontia holosericea (Weinm.) O'Donell & Schizomyia santosi Maia \& Araújo, 2009 \\
\hline Lantana camara L. & Schismatodiplosis lantanae (Rübsaamen, 1916) \\
\hline Manilkara subsericea (Mart.) Dubard & Manilkaramyia notabilis Maia, 2001 \\
\hline Melissa officinalis L. & Clinodiplosis melissae Maia, 1994 \\
\hline \multicolumn{2}{|c|}{ Microgramma vacciniifolia (Langsd. \& Fisch.) Copel. Primadiplosis microgramma Maia, 2011} \\
\hline Microstachys corniculata (Vahl) Griseb. & Clinodiplosis conica Oliveira \& Maia, 2008 \\
\hline Microstachys corniculata (Vahl) Griseb. & Schizomyia spherica Maia \& Oliveira, 2007 \\
\hline Monteverdia obtusifolia (Mart.) Biral & Bruggmanniella maytenuse (Maia \& Couri, 1992) \\
\hline Monteverdia obtusifolia (Mart.) Biral & Mayteniella distincta Maia, 2001 \\
\hline Myrcia ovata Cambess. & Myrciamyia maricaensis Maia, 1996 \\
\hline Myrciaria floribunda (H.West ex Willd.) 0. Berg & Dasineura myrciariae Maia, 1995 \\
\hline Myrciaria floribunda (H.West ex Willd.) 0. Berg & Myrciariamyia bivalva Maia, 1994 \\
\hline Neomitranthes obscura (DC.) N.Silveira & Neomitranthella robusta Maia, 1995 \\
\hline Neomitranthes obscura (DC.) N.Silveira & Stephomyia mina Maia, 1993 \\
\hline Paullinia weinmanniifolia Mart. & Clinodiplosis costai Maia, 2005 \\
\hline Paullinia weinmanniifolia Mart. & Paulliniamyia ampla Maia, 2001 \\
\hline Peplonia asteria (Vell.) Fontella \& E.A. Schwarz & Asphondylia peploniae Maia, 2001 \\
\hline Pouteria caimito (Ruiz \& Pav.) Radllk. & Youngomyia pouteriae Maia, 2001 \\
\hline Pouteria venosa (Mart.) Baehni & Lopesia singularis Maia, 2001 \\
\hline Protium brasiliense (Spreng.) Engl. & Lopesia maricaensis Rodrigues \& Maia, 2010 \\
\hline Psittacanthus dichroos (Mart.) Mart. & Costadiplosis maricaensis Viceconte \& Maia, 2009 \\
\hline Senna bicapsularis (L.) Roxb. & Asphondylia sennae Maia \& Couri, 1992 \\
\hline Smilax rufescens Griseb. & Smilasioptera candelariae Möhn, 1975 \\
\hline Struthanthus taubatensis Eichler & Asphondylia maricensis Maia \& Couri, 1992 \\
\hline Tetrapterys phlomoides (Spreng.) Nied. & Schizomyia maricaensis Sousa \& Maia, 2007 \\
\hline Varronia curassavica Jacq. & Asphondylia cordiae Möhn, 1959 \\
\hline Varronia curassavica Jacq. & Cordiamyia globosa Maia, 1996 \\
\hline Ximenia americana $\mathrm{L}$. & Asphondylia communis Maia \& Couri, 1992 \\
\hline
\end{tabular}

The Restinga of Barra de Maricá is located in the municipality of Maricá, Rio de Janeiro, Brazil $\left(22^{\circ} 52^{\prime}-22^{\circ} 54^{\prime} \mathrm{S}\right.$ and $42^{\circ} 48^{\prime}-42^{\circ} 54^{\prime} \mathrm{W}$ ). This restinga has $8 \mathrm{~km}$ of extension and 844.16 ha of total area (Santos et al., 2017). The climate of the Maricá region is classified as hot tropical, super humid, with a dry season (Alvares et al., 2013). The region has an average annual temperature of $23.2^{\circ} \mathrm{C}$ and the average annual precipitation is $1,230.8 \mathrm{~mm}$ (Santos et al., 2017). It comprises several microenvironment and vegetal formations, which characterize this complex ecosystem with a very diverse flora (Oliveira \& Silva, 1989).

\section{Data analyses}

The structure of interactions between host plants and gall midges was evaluated using three topological descriptors: connectance, number of links per species, modularity, and robustness. Connectance $(C)$ is the proportion of observed interactions compared to the possible interactions in the network ranging of 0 (totally specialized) to 1 (totally connected) (Dormann et al., 2009). Number of links per species (L) is the sum of links divided by number of species. Modularity (M) is a measure of the occurrence of densely connected modules within the network (Dormann et al., 2009), ranging between 0 (when the network is not modular) and 1 (when a network is very modular). Robustness $(R)$ is a measure of the resistance level of the network to coextinctions (Dormann et al., 2009), measured as the exponent of the curve generated by the proportion of remaining species of gall midges in function of the proportion of primary random extinctions of host plant species. The significance of observed values of each network descriptor was calculated using null models (Dormann et al., 2009). All network analyses were performed using bipartite package (Dormann et al., 2008) in the R software version 3.6.1 (R Core Team, 2020).

\section{RESULTS}

In total, we recorded 56 species of 27 genera of gall midges and 36 species of 32 genera and 24 families of host plants (Table 1). The richest gall-midge genera were Asphondylia Loew, 1850 and Dasineura Rondani, 1840, each with six species. All species of gall midges recorded are gall-inducers, except Clinodiplosis floricola NovoGuedes \& Maia, 2008 that is a free-living herbivore. All gall-midge species were monophagous, inducing galls on only one plant species (Table 1).

The host plants Guapira opposita (Vell.) Reitz (Nyctaginaceae), Eugenia astringens Cambess. and Eugenia uniflora L. sheltered more gall midges, with seven, three and three species, respectively (Table 1). The most important host family was Myrtaceae with six plant species and 13 gall-midge species. The genus Eugenia L. (Myrtaceae) stands out for having three species of host plants and eight species of gall midges.

The plant-galling network comprised 56 interactions (Fig. 1), corresponding to only $2.8 \%$ of the 2,016 possi- 

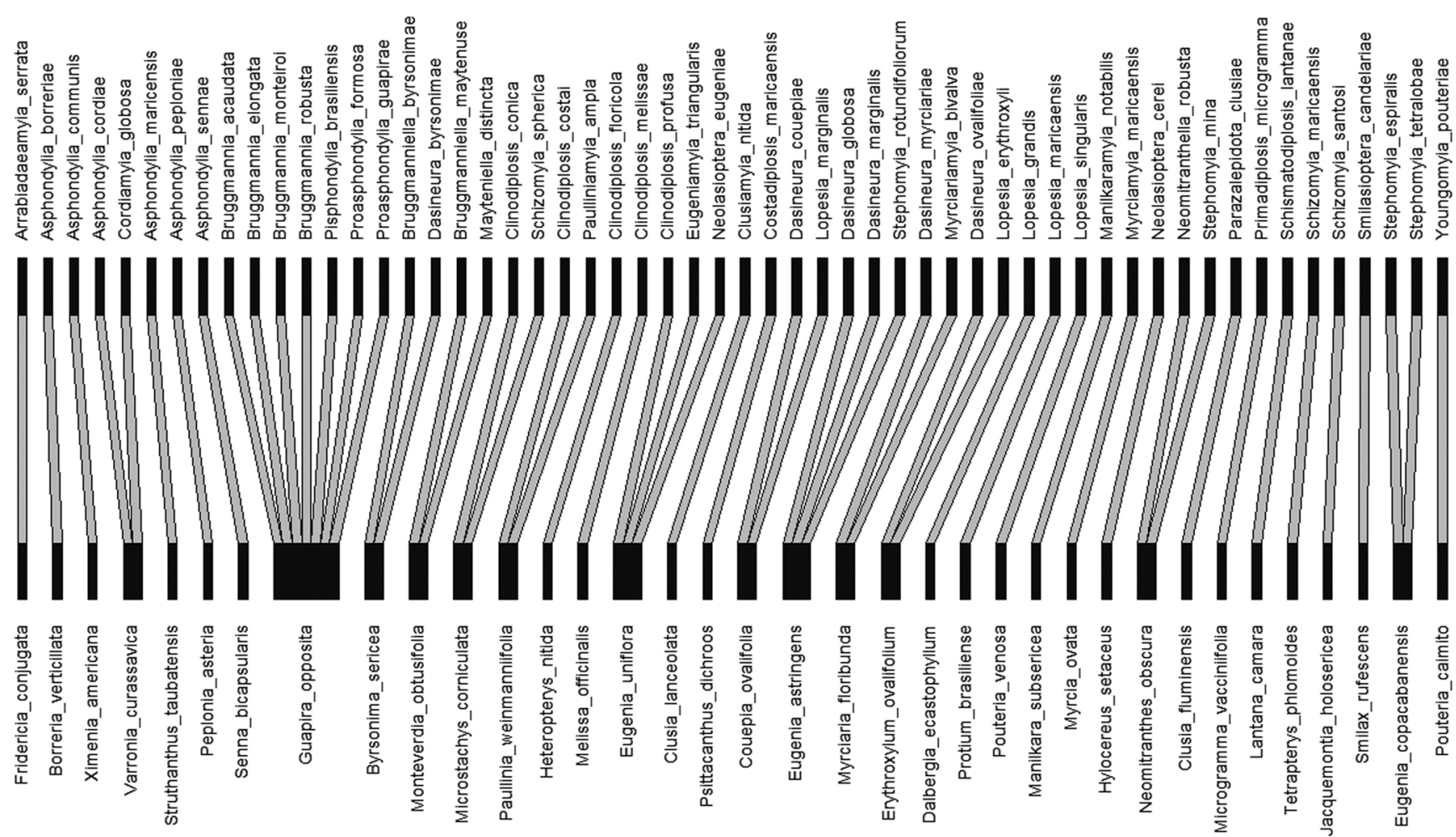

Figure 1. Bipartite network of host plants and gall midge species at the Restinga of Barra de Maricá (Maricá, RJ, Brazil). Lower bars represent host plant species and upper bars represent gall-midge species; grey bars represent interactions. Bar thickness is proportional to the number of interactions of each species.

ble interactions. The observed connectance $(C=0.028)$ was lower than expected from null model values (Null $\mathrm{C}=0.032 \pm 0.001, \mathrm{p}<0.001)$. Similarly, the observed number of links per species $(L=0.608)$ also was lower than expected by chance (Null $L=0.710 \pm 0.020, p<0.001$ ). The observed modularity for plant-galling network was very high ( $M=0.958)$, but did not differ from null model values (Null $M=0.959 \pm 0.001, p>0.05$ ). Robustness observed was relatively low $(R=1.343)$, but was higher than expected by chance (Null $R=1.334 \pm 0.232, p<0.001$ ).

\section{DISCUSSION}

We found a high specialization of interactions between host plants and gall midges in the present study, confirming previous studies (Carneiro et al., 2009; Araújo et al., 2019b). All species of gall midges were recorded on a single host plant species (i.e., monophagous species). The percentage of specialist species recorded in our study is higher than found by Carneiro et al. (2009) which recorded $92 \%$ of monophagous gall midges for Brazil. In other study, Araújo et al. (2019b) recorded that $79 \%$ of gall-midge species were monophages in the Slovakia. These results suggest a lower specialization of gall midges in temperate environments when compared to the Neotropical region, which have more specific gallers in their host plants, as observed for the Restinga of Barra de Maricá. It is important to note that there are differences in the duration and frequency of sampling between the present study and the others mentioned. Our network was sampled for a much longer period of time than any previously published study (almost two decades), which enhances the sampling of rarer interactions, and consequently increases the specialization of the network. However, this fact reinforces the relevance of the observed patterns, because even with such a long sampling, only species-specific plant-galling interactions were registered.

The structure of the network formed by the gall midges and their host plants proved to be highly specialized. The connectance observed in the present study (2.8\%) was low as compared to other plant-phytophagous networks (review in Araújo et al., 2015). However, comparing with other networks of galling arthropods, the value observed here was higher than observed by Araújo et al. (2017) (2.3\%) but lower to that observed by Araújo \& Kollar (2019) (5.4\%), which sampled networks in temperate forests. Our plant-galling network also showed a low number of links per species (0.608) and a high modularity (0.958), corroborating the pattern observed in other galling networks (Araújo et al., 2017; Araújo \& Kollar, 2019). Our results provide evidence that supports the high specificity and specialization of plant-galling interactions (Araújo et al., 2019b). Furthermore, our results show that the network of host plants and gall midges is few robust to coextinctions. This result is due to the high specificity of the plant-galling interactions, since each species of plant lost, represents the loss of at least one species of gall midge (Araújo et al., 2017).

Main genera of gall midges recorded in our study were Dasineura and Asphondylia. The genus Dasineura is the richest in Cecidomyiidae family with 476 described species (Gagné \& Jaschhof, 2017). For the Neotropical region, only 39 species in this genus are described, 10 species from Brazil (Maia \& Silva, 2013). In the present study, 
Dasineura induced galls mainly on Myrtaceae (but also on Chrysobalanaceae, Erythroxylaceae, and Malpighiaceae). The genus Asphondylia is cosmopolitan and includes 272 gall-inducing species in the world and 100 in the Neotropical region (Gagné \& Jaschhof, 2017). In Brazil, Flor \& Maia (2017) listed 58 species of Asphondylia, being 20 are already known and 38 are still undetermined. In the Restinga of Maricá, Asphondylia induced galls on host plants of six families (Asclepiadaceae, Boraginaceae, Fabaceae, Loranthaceae, Olacaceae, and Rubiaceae). These two genera are characterized by highly specialized galling species, most of which are monophages (Carneiro et al., 2009), which contributed to the low connectivity of the plant-galling network.

Myrtaceae was the plant family that sheltered more gall-midge species (13 species) and presented important host plants (in terms of the number of interactions), such as Eugenia astringens, and Eugenia uniflora (three gall midge species each). Myrtaceae are one of the most diverse families of Angiospermae, with thousands of species, being important in several Neotropical ecosystems (Wilson et al., 2001). Eugenia, with about 1,000 species, is one of the most diverse genera of Myrtaceae, distributed mainly in the Central and South Americas (Merwe et al., 2004), being the genus with the greatest number of species at restingas in the State of Rio de Janeiro (Araújo \& Henriques, 1984). The great number of gall midges associated to Myrtaceae plants contributed to the high modularity of the plant-galling network, since the family forms a compartment of interactions within the network. Similarly, Guapira opposita, which was the host plant species that sheltered more gall-midge species with seven species, it also contributed to the formation of a module within the network. This species is one of the most expressive plants in Quaternary coastal plains of the Atlantic Coast of Southern Brazil, very frequent at restingas, where it is widespread and one of the dominant species (Reitz, 1970).

The frequency and abundance of these plant taxa can explain the great diversity of gall-inducers associated with them. In fact, Myrtaceae have been cited in several gall inventories at restinga areas as super host family, not only in the State of Rio Janeiro, as Maricá and Carapebus (Maia, 2001), Grumari (Oliveira \& Maia, 2005), Ilha da Marambaia (Rodrigues et al., 2014), Ilha Grande (Maia \& Oliveira, 2010), Região dos Lagos (CarvalhoFernandes et al., 2016), but also in Espírito-Santo (in Guarapari) (Bregonci et al., 2010), São Paulo (in Bertioga) (Maia et al., 2008), and Santa Catarina (in Babitonga and São Francisco do Sul) (Melo-Júnior et al., 2018; Arriola et al., 2015). The frequent presence of Myrtaceae in gall inventories at Brazilian restinga is an indication of the importance of this family for the structuring of plant-galling communities in these ecosystems. Similarly, Guapira opposita is cited as super host species in almost all inventories at restinga (review in Maia, 2013), except in Grumari and Guarapari. Recent evidence suggests that the presence of super host taxa can modify the structure of plant-galling networks in Neotropical environments, increasing the diversity and connectivity of interactions
(Araújo et al., 2019c). In addition, the presence of super host species can impact the robustness of the network, because although it increases the robustness for random extinctions, the presence of closely connected species makes the network more vulnerable to directional attack (lyer et al., 2013). These evidences suggest that Guapira opposita may have a great importance in structuring plant-galling networks in restingas, but more data are needed to measure its real role.

There is a large Linean gap in the knowledge of Neotropical cecidomyiids (Araújo et al., 2019a), which is one of the main limitations for the advancement of studies on the biology and ecology of gall-midge interactions with other species. In the present study, by using a taxonomically well-defined trophic assemblage, we elucidated for the first time the structure of a network involving host plants and gall midges in the Neotropical region. Our results show highly specialized patterns both for the interactions of gall midges with their plants. The low connectance and high modularity observed for plant-galling interactions indicates a high level of ecological and phylogenetic restrictions for the structuring of interactions within the network, which demonstrates that eventual losses of species or interactions can be hardly substituted. Thus, this high level of specificity reinforces the important of conserving this so threatened ecosystem, as each restinga area has a peculiar flora and consequently a unique assemblage of host plants and gall-midge species.

\section{ACKNOWLEDGMENTS}

We are grateful to the Conselho Nacional de Desenvolvimento Científico e Tecnológico (CNPq) for financial support (Proc. 301481/2017-2).

\section{AUTHORS' CONTRIBUTIONS}

W.S.A.: Conceptualization, Formal analysis, Writing - original draft, Visualization, Investigation, Writing - review \& editing. V.C.M.: Conceptualization, Methodology, Data curation, Writing - original draft, Visualization, Investigation, Writing - review \& editing. All the authors actively participated in the discussion of the results, they reviewed and approved the final version of the paper. Authors declare there are no conflicts of interest.

\section{REFERENCES}

Alvares, C.A.; Stape, J.L.; Sentelhas, P.C.; Gonçalves, J.L.M. \& Sparovek, G. 2013. Köppen's climate classifcation map for Brazil. Meteorologische Zeitschrift, 22(6): 711-728.

Araújo, D.S.D. \& Henriques, R.P.B. 1984. Análise florística das restingas do Estado do Rio de Janeiro. In: Lacerda, L.D.; Araújo, D.S.D.; Cerqueira, R. \& Turcq, B. Restingas: origem, estrutura e processos. Niteroi, CEUFF. p. 159-193.

Araújo, W.S. \& Kollár, J. 2019. First characterization of a highly specialized ecological network composed by gall-inducing mites and their host plants. International Journal of Acarology, 45(4): 223-226. 
Araújo, W.S.; Fernandes, G.W. \& Santos, J.C. 2019a. An overview of inventories of gall-inducing insects in Brazil: looking for patterns and identifying knowledge gaps. Anais da Academia Brasileira de Ciências, 91(1): e20180162.

Araújo, W.S.; Freitas, É.V.D.; Kollár, J.; Pessoa, R.0.; Corgosinho, P.H.C.; Valério, H.M.; Falcão, L.A.D.; Fagundes, M.; Pimenta, M.A.S.; Faria, M.L.; Borges, M.A.Z. \& Martins, W.P. 2019b. Host Specialization in Plant-galling Interactions: Contrasting Mites and Insects. Diversity, 11: 180.

Araújo, W.S.; Moreira, L.T.; Falcão, L.A.D.; Borges, M.A.Z.; Fagundes, M.; Faria, M.L.D. \& Guilherme, F.A.G. 2019c. Superhost plants alter the structure of plant-galling insect networks in Neotropical Savannas. Plants, 8: 369.

Araújo, W.S.; Grandez-Rios, J.M.; Bergamini, L.L. \& Kollár, J. 2017. Exotic species and the structure of a plant-galling network. Network Biology, 7: 21-32.

Araújo, W.S.; Vieira, M.C.; Lewinsohn, T.M. \& Almeida-Neto, M. 2015. Contrasting effects of land use intensity and exotic host plants on the specialization of interactions in plant-herbivore networks. Plos One, 10: e0115606.

Arriola, I.A.; Melo-Júnior, J.C.F. \& Isaias, R.M.S. 2015. Questioning the environmental stress hypothesis for gall diversity of restinga vegetation on dunes. Revista de Biología Tropical, 63(4): 959-970.

Bregonci, J.M.; Polycarpo, P.V. \& Maia, V.C. 2010. Galhas de insetos do Parque Estadual Paulo César Vinha (Guarapari, ES, Brasil). Biota Neotropica, 10: $1-10$.

Carneiro, M.A.A.; Branco, C.S.; Braga, C.E.; Almada, E.D.; Costa, M.; Maia, V.C. \& Fernandes, G.W. 2009. Are gall midge species (Diptera, Cecidomyiidae) host plant specialists? Revista Brasileira de Entomologia, 53(3): 365-378.

Carvalho-Fernandes, S.P.; Ascendino, S.; Maia, V.C. \& Couri, M.S. 2016. Diversity of insect galls associated with coastal shrub vegetation. Anais da Academia Brasileira de Ciências, 88(3): 1407-1418.

Dormann, C.F.; Fründ, J.; Blüthgen, N. \& Gruber, B. 2009. Indices, graphs and null models: analyzing bipartite ecological networks. The Open Ecology Journal, 2: 7-24.

Dormann, C.F.; Gruber, B. \& Fründ, J. 2008. Introducing the bipartite package: analysing ecological networks. R News, 8: 8-11.

Fernandes, G.W. \& Santos, J.C. 2014. Neotropical insect galls. New York, Springer.

Flor, I.C. \& Maia, V.C. 2017. Representativity of the genus Asphondylia Loew, 1850 (Diptera, Cecidomyiidae) in Brazil. Papéis Avulsos de Zoologia, 57(30): 393-404.

Flora do Brasil. 2020. Jardim Botânico do Rio de Janeiro [under construction]. Available: http://floradobrasil.jbrj.gov.br. Access: 25/05/2019.

Gagné, R.J. 1994. The Gall-midges of the Neotropical region. Comstock, Cornell University Press.

Gagné, R.J. \& Jaschhof, M. 2017. A catalog of the Cecidomyiidae (Diptera) of the world. 4. Ed. Available: https://www.ars.usda.gov/
ARSUserFiles/80420580/Gagne 2017 World Cat 4th ed.pdf. Access: 20/06/2020.

lyer, S.; Killingback, T.; Sundaram, B. \& Wang, Z. 2013. Attack robustness and centrality of complex networks. PloS One, 8: e59613.

Maia, V.C. 2001. The gall-midges (Diptera, Cecidomyiidae) from three restingas of Rio de Janeiro State, Brazil. Revista Brasileira de Zoologia, 18(2): 583-629.

Maia, V.C. 2013. Galhas de insetos em restingas da região sudeste do Brasil com novos registros. Biota Neotropica, 13: 183-209.

Maia, V.C. \& Oliveira, J.C. 2010. Galhas de insetos da Reserva Biológica Estadual da Praia do Sul (Ilha Grande, Angra dos Reis, RJ). Biota Neotropica, 10: 227-238.

Maia, V.C. \& Silva, L.0. 2013. The genus Dasineura Rondani, 1840 (Diptera, (ecidomyiidae) in Brazil. Brazilian Journal of Biology, 73(4): 801-807.

Maia, V.C.; Magenta, M.A.G. \& Martins, S.E. 2008. Ocorrência e caracterização de galhas de insetos em áreas de restinga de Bertioga (São Paulo, Brasil). Biota Neotropica, 8: 167-197.

Melo-Júnior, J.C.F.; Isaias, R.M.S.; Boeger, M.C.T.; Arriola, I.A.; \& MatildeSilva, M. 2018. Diversidade de galhadores nas restingas do ecossistema Babitonga, Santa Catarina, Brasil. Revista CEPSUL, 7: eb2018003.

Merwe, M.M.; Wyk, A.E. \& Botha, A.M. 2004. Molecular phylogenetic analysis of Eugenia L. (Myrtaceae), with emphasis on southern Africa taxa. Plant Systematic Evolution, 251: 21-34.

Oliveira, A.S. \& Silva, J.G. 1989. A Vegetação de Restinga no Município de Maricá, RJ. Acta Botanica Brasileira, 3: 253-272.

Oliveira, J. \& Maia, V.C. 2005. Ocorrência e caracterização de galhas de insetos na restinga de Grumari (Rio de Janeiro, RJ, Brasil). Arquivos do Museu Nacional, Rio de Janeiro, 63(4): 669-676.

Reitz, R. 1970. Flora Ilustrada Catarinense. Nyctaginaceae. Itajaí, Herbário Barbosa Rodrigues.

Rodrigues, A.R.; Maia, V.C. \& Couri, M.S. 2014. Insect galls of restinga areas of Ilha da Marambaia, Rio de Janeiro, Brazil. Revista Brasileira de Entomologia, 58(2): 173-197.

Santos, C.P.; Coe, H.H.G.; Ramos, Y.B.M.; Sousa, L.O.F.; Silva, A.L.C.S.; Freire, D.G. \& Silvestre, C.P. 2017. Caracterização das Comunidades Vegetais na Restinga de Maricá, Rio de Janeiro, Sudeste do Brasil. Revista Tamoios, 13: 121-135.

The R Project for Statistical Computing (R Core Team). 2020. R: A language and environment for statistical computing. Vienna, R Foundation for Statistical Computing.

Wilson, G.W.; O'Brien, M.M.; Gadek, P.A. \& Quinn, C.J. 2001. Myrtaceae revisited: a reassessment of intrafamilial groups. American Journal of Botany, 88: 2013-2025. 


\section{APPENDIX S1}

\section{List of published data compiled in the present study.}

\section{RESTINGA OF THE BARRA DE MARICÁ (APA)}

1) Host plant:

Galler:

Parasitoid:

Refs.:

2) Host plant:

Galler:

Parasitoids:

Refs.:

3) Host plant:

Galler:

Parasitoids:

Refs.:

4) Host plant:

Galler:

Parasitoid:

Refs.:

Galler:

Parasitoids:

Refs.:

5) Host plant:

Galler:

Parasitoids:

Refs.:

6) Host plant:

Galler:

Parasitoids:

Refs.:

7) Host plant:

Galler:

Parasitoids:

Refs.:

8) Host plant:

Galler:

Parasitoids:

Refs.:

Galler:

Parasitoids:

Refs.:

Galler:

Parasitoids:

Refs.:

Galler:

Parasitoids:

Refs.:

Galler:

Parasitoids:

Refs.:

Galler:

Parasitoids:

Refs.:

Galler:
Fridericia conjugata (Vell.) L.G. Lohmann (Bignoniaceae) (= Arrabidaea conjugata) (native to Brazil)

Arrabiadaeamyia serrata Maia 2001a

Eurytoma sp. 1 (Eurytomidae)

Maia 2001a, b, Maia \& Azevedo 2009

Borreria verticillata (L.) G. Mey. (Rubiaceae) (native to Brazil)

Asphondylia borreriae Rübsaamen 1905

Horismenus sp. (Eulophidae), Eupelmidae, Rileya sp. 7 (Eurytomidae)

Rübsaamen 1905, Maia 2001b, Maia \& Azevedo 2009

Ximenia americana L. (0lacaceae) (native to Brazil)

Asphondylia communis Maia \& Couri 1992

Encyrtidae, Eupelmidae

Maia \& Couri 1992, Maia 2001b, Maia \& Azevedo 2009

Varronia curassavica Jacq. (= Cordia verbenacea DC. = Cordia curassavica (Jacq.) Roem. \& Schult.) (Boraginaceae) (native to Brazil)

Asphondylia cordiae Möhn 1959

Eurytoma sp. 2 (Eurytomidae)

Möhn 1959, Maia 2001b, Maia \& Azevedo 2009

Cordiamyia globosa Maia 1996a

Cirrospilus sp. 1, Galeopsomyia sp. 1 (Eulophidae), Synopeas sp. (Platygastridae), Lyrcus sp. (Pteromalidae), Dimeromicrus

cecidomyiae, Torymoides sp.; Torymus sp. (Torymidae)

Maia 1996a, Maia 2001b, Maia \& Azevedo 2009

Struthanthus taubatensis Eichler (= S. maricensis Rizzini ex Profice (Loranthaceae) (endemic to Brazil)

Asphondylia maricensis Maia \& Couri 1992

Eurytomidae, Platygaster sp. (Platygastridae)

Maia \& Couri 1992, Maia 2001b, Maia \& Azevedo 2009

Peplonia asteria (Vell.) Fontella \& E.A. Schwarz (Asclepiadaceae) (endemic to Atlantic Forest)

Asphondylia peploniae Maia 2001 a

Eulophidae, Rileya sp. 1 (Eurytomidae), Torymidae

Maia 2001a, b, Maia \& Azevedo 2009

Senna bicapsularis (L.) Roxb. (Fabaceae) (exotic)

Asphondylia sennae Maia \& Couri 1992

No parasitoids

Maia \& Couri 1992

Guapira opposita (Vell.) Reitz (Nyctaginaceae) (native to Brazil)

Bruggmannia acaudata Maia 2004

Galeopsomyia sp. 1 (Eulophidae), Eupelmidae, Eurytoma sp. 9, Rileya sp. 3 (Eurytomidae), Torymidae

Maia 2001b, Maia 2004, Maia \& Azevedo 2009

Bruggmannia elongata Maia \& Couri 1993

Eupelmidae, Galeopsomyia sp. 1, Chrysotomyia sp., Cirrospilus sp. (Eulophidae), Rileya sp. 3, Eurytoma sp. 9 (Eurytomidae),

Platygaster sp. (Platygastridae)

Maia \& Couri 1993, Maia 2001b, Maia \& Azevedo 2009

Bruggmannia monteiroi Maia \& Couri 1993

No parasitoids.

Maia \& Couri 1993

Bruggmannia robusta Maia \& Couri 1993

Eupelmidae, Galeopsomyia sp. 1, Chrysotomyia sp. (Eulophidae), Eurytoma sp., Rileya sp. 3 (Eurytomidae), Platygaster sp.

(Platygastridae)

Maia \& Couri 1993, Maia 2001b, Maia \& Azevedo 2009

Pisphondylia brasiliensis Couri \& Maia 1992

No parasitoids.

Couri \& Maia 1992, Maia 2001b

Proasphondylia formosa Maia 1994a

No parasitoids.

Maia 1994a, Maia \& Azevedo 2009

Proasphondylia guapirae Maia 1994a 


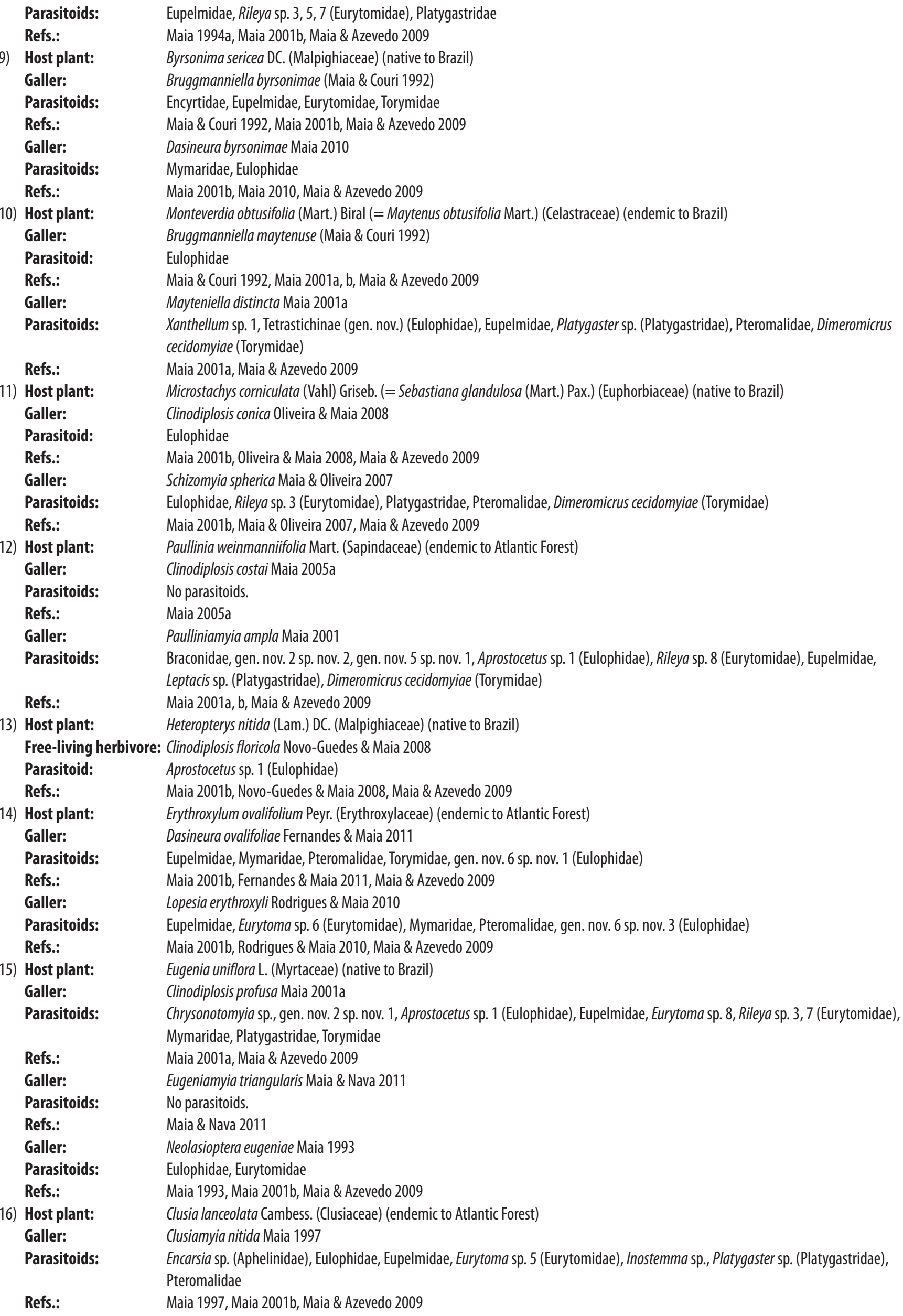


17) Host plant:

Galler:

Parasitoids:

Refs.:

18) Host plant:

Galler:

Parasitoids:

Refs.:

19) Host plant:

Galler:

Parasitoids:

Refs.:

Galler:

Parasitoids:

Refs.:

20) Host plant:

Galler:

Parasitoids:

Refs.:

Galler:

Parasitoids:

Refs.:

Galler:

Parasitoids:

Refs.:

21) Host plant:

Galler:

Parasitoids:

Refs.:

Galler:

Parasitoids:

Refs.:

22) Host plant:

Galler:

Parasitoids:

Refs.:

Galler:

Parasitoids:

Refs.:

23) Host plant:

Galler:

Parasitoid:

Refs.:

24) Host plant:

Galler:

Parasitoids:

Refs.:

25) Host plant:

Galler:

Parasitoids:

Refs.:

26) Host plant:

Galler:

Parasitoids:

Refs.:

27) Host plant:

Galler:

Parasitoids:

Refs.:
Melissa officinalis L. (Lamiaceae) (exotic)

Clinodiplosis melissae Maia 1994b

No parasitoids.

Maia 1994b

Psittacanthus dichroos (Mart.) Mart. (Loranthaceae) (endemic to Brazil)

Costadiplosis maricaensis Viceconte \& Maia 2009

Aprostocetus sp. 1 (Eulophidae), Pteromalidae

Maia 2001b, Viceconte \& Maia 2009, Maia \& Azevedo 2009

Couepia ovalifolia (Schott) Benth. ex Hook.f. (Chrysobalanaceae) (endemic to Atlantic Forest)

Dasineura couepiae Maia 2001a

Aphelinidae, Braconidae, Eulophidae, Eupelmidae, Torymidae

Maia 2001a, b, Maia \& Azevedo 2009

Lopesia marginalis Maia 2001a

Eupelmidae, Pteromalidae, Torymidae

Maia 2001a, b, Maia \& Azevedo 2009

Eugenia astringens Cambess. (= Eugenia rotundifolia Casar) (Myrtaceae) (endemic to Atlantic Forest)

Dasineura globosa Maia 1996b

Eulophidae, Platygaster sp. (Platygastridae), Torymidae

Maia 1996b, Maia 2001b, Maia \& Azevedo 2009

Dasineura marginalis Maia 2005b

Closterocerus sp. 1, Pentastichus sp. 1, gen. nov. 6 sp. nov. 2, gen. nov. 4 sp. nov. 1 (Eulophidae), Torymidae

Maia 2001b, Maia 2005b, Maia \& Azevedo 2009

Stephomyia rotundifoliorum Maia 1994c

Donquickeia sp. (Braconidae), Eulophidae, Brasema sp. (Eupelmidae), Rileya sp. 5, Eurytoma sp. 7 (Eurytomidae), Platygastridae,

Dimeromicrus cecidomyiae (Torymidae)

Maia 1994c, Maia 2001b, Maia \& Azevedo 2009

Myrciaria floribunda (H. West ex Willd.) 0. Berg (Myrtaceae) (native to Brazil)

Dasineura myrciariae Maia 1996

Dimeromicrus cecidomyiae (Torymidae)

Maia 1996b, Maia 2001b, Maia \& Azevedo 2009

Myrciariamyia bivalva Maia 1995

Encyrtidae, Pteromalidae, gen. nov. 3 sp. nov. (Eulophidae)

Maia 1995, Maia 2001b, Maia \& Azevedo 2009

Neomitranthes obscura (DC.) N. Silveira (Myrtaceae) (endemic to Atlantic Forest)

Neomitranthella robusta Maia $1996 \mathrm{c}$

Quadrastichus sp., Tetrastichinae (gen. nov.) (Eulophidae)

Maia 1996c, Maia 2001b, Maia \& Azevedo 2009

Stephomyia mina Maia 1994c

Braconidae, Quadrastichus sp., Aprostocetus sp. 4 (Eulophidae), Eupelmidae, Eurytomidae, Platygastridae

Maia 1994c, Maia 2001b, Maia \& Azevedo 2009

Dalbergia ecastophyllum (L.) Taub. (Fabaceae) (native to Brazil)

Lopesia grandis Maia 2001a

Torymidae

Maia 2001a, b, Maia \& Azevedo 2009

Protium brasiliense (Spreng.) Engl. (Burseraceae) endemic to Brazil)

Lopesia maricaensis Rodrigues \& Maia 2010

Goniozus sp. (Bethylidae), Aprostocetus sp. (Eulophidae), Brasema sp. (Eupelmidae)

Maia 2001b, Rodrigues \& Maia 2010, Maia \& Azevedo 2009

Pouteria venosa (Mart.) Baehni (Sapotaceae) (native to Brazil)

Lopesia singularis Maia 2001a

Tetrastichinae (gen. nov.) (Eulophidae), Eupelmidae, Eurytomidae, Platygastridae, Torymidae

Maia 2001a, b, Maia \& Azevedo 2009

Manilkara subsericea (Mart.) Dubard (Sapotaceae) (endemic to Atlantic Forest)

Manilkaramyia notabilis Maia 2001a

No parasitoids.

Maia 2001a, b

Myrcia ovata Cambess. (Myrtaceae) (endemic to Atlantic Forest)

Myrciamyia maricaensis Maia $1996 c$

gen. nov. 1 sp. nov. 1, gen. nov. 3 sp. nov. 1, Aprostocetus sp. 3 (Eulophidae)

Maia 1996c, Maia 2001b, Maia \& Azevedo 2009 
28) Host plant: Galler:

Parasitoids: Refs.:

29) Host plant: Galler: Parasitoid: Refs.:

30) Host plant: Galler: Parasitoids: Refs.:

31) Host plant: Galler: Parasitoids: Refs.:

32) Host plant: Galler: Parasitoids: Refs.:

33) Host plant: Galler: Parasitoids: Refs.:

34) Host plant: Galler:

Parasitoids: Refs.:

35) Host plant: Galler: Parasitoid: Refs.:

Galler:

Parasitoids: Refs.:

36) Host plant: Galler: Parasitoids: Refs.:
Hylocereus setaceus (Salm-Dyck) R. Bauer (= Selenicereus setaceus (Salm-Dyck) Berg (Cactaceae) (native to Brazil) Neolasioptera cerei (Rübsaamen 1905):

No parasitoids.

Rübsaamen 1905, Maia 2001b

Clusia fluminensis Planch. \& Triana (Clusiaceae) (endemic to Atlantic Forest)

Parazalepidota clusiae Maia 2001a

Rileya sp. 2 (Eurytomidae)

Maia 2001a, b, Maia \& Azevedo 2009

Microgramma vacciniifolia (Langsd. \& Fisch.) Copel. (Polypodiaceae) (native to Brazil)

Primadiplosis microgramma Maia 2011

Eulophidae, Torymidae

Maia 2011, Maia \& Santos 2015

Lantana camara L. (Verbenaceae) (naturalised)

Schismatodiplosis lantanae (Rübsaamen 1908)

Eulophidae, Platygastridae, Pteromalidae, Scelionidae

Rübsaamen 1908, Maia 2001b, Maia \& Azevedo 2009

Tetrapterys phlomoides (Spreng.) Nied. (Malpighiaceae) (native to Brazil)

Schizomyia maricaensis Sousa \& Maia 2007

No parasitoids.

Maia 2001b, Sousa \& Maia 2007

Jacquemontia holosericea (Weinm.) O'Donell (Convolvulaceae) (native to Brazil)

Schizomyia santosi Maia \& Araújo 2009

No parasitoids.

Maia 2001b, Maia \& Araújo 2009

Smilax rufescens Griseb. (Smilacaceae) (endemic to Brazil)

Smilasioptera candelariae Möhn 1975

Pentastichus sp. 3 (Eulophidae), Eupelmidae

Möhn 1975, Maia 2001b, Maia \& Azevedo 2009

Eugenia copacabanensis Kiaersk. (Myrtaceae) (endemic to Atlantic Forest)

Stephomyia espiralis Maia 1994c

Tetrastichinae (gen. nov.) (Eulophidae)

Maia 1994c, Maia 2001b, Maia \& Azevedo 2009

Stephomyia tetralobae Maia 1994c

Eupelmidae, Rileya sp. 6 (Eurytomidae)

Maia 1994c, Maia 2001b, Maia \& Azevedo 2009

Pouteria caimito (Ruiz \& Pav.) Radlk (= Pouteria caimito var. laurifolia) (Sapotaceae) (native to Brazil)

Youngomyia pouteriae Maia 2001a

Xanthobium sp. (Eulophidae), Eupelmidae, Platygastridae, Dimeromicrus cecidomyiae (Torymidae)

Maia 2001a, b, Maia \& Azevedo 2009

\section{RESTINGA OF THE ITAIPUAÇU}

1) Host plant: Galler:

Parasitoid: Refs.:

2) Host plant: Galler: Parasitoids: Refs.:

3) Host plant:

Galler:

Parasitoid:

Refs.:

Galler: Parasitoids:
Fridericia conjugata (Vell.) L.G. Lohmann (Bignoniaceae) (= Arrabidaea conjugata) (native to Brazil) Arrabiadaeamyia serrata Maia 2001a

Eurytoma sp. 1 (Eurytomidae)

Maia 2001a, b, Maia \& Azevedo 2009

Ximenia americana L. (0lacaceae) (native to Brazil)

Asphondylia communis Maia \& Couri 1992

Encyrtidae, Eupelmidae

Maia \& Couri 1992, Maia 2001b, Maia \& Azevedo 2009

Varronia curassavica Jacq. (= Cordia verbenacea DC. = Cordia curassavica (Jacq.) Roem. \& Schult.) (Boraginaceae) (native to Brazil) Asphondylia cordiae Möhn 1959

Eurytoma sp. 2 (Eurytomidae)

Möhn 1959, Maia 2001b, Maia \& Azevedo 2009

Cordiamyia globosa Maia 1996a

Cirrospilus sp. 1, Galeopsomyia sp. 1 (Eulophidae), Synopeas sp. (Platygastridae), Lyrcus sp. (Pteromalidae), Dimeromicrus cecidomyiae, Torymoides sp.; Torymus sp. (Torymidae)

Refs.: Maia 1996a, Maia 2001b, Maia \& Azevedo 2009 
4) Host plant:

Galler:

Parasitoids:

Refs.:

5) Host plant:

Galler:

Parasitoids:

Refs.:

6) Host plant:

Galler:

Parasitoids:

Refs.:

Galler:

Parasitoids:

Refs.:

Galler:

Parasitoids:

Refs.:

Galler:

Parasitoids:

Refs.:

7) Host plant:

Galler:

Parasitoids:

Refs.:

8) Host plant:

Galler:

Parasitoids:

Refs.:

9) Host plant:

Galler:

Parasitoid:

Refs.:

10) Host plant:

Galler:

Parasitoids:

Refs.:

Galler:

Parasitoids:

Refs.:

11) Host plant:

Free-living herbivore:

Parasitoid:

Refs.:

12) Host plant:

Galler:

Parasitoids:

Refs.:

Galler:

Parasitoids:

Refs.:

13) Host plant:

Galler:

Parasitoids:
Struthanthus taubatensis Eichler (= S. maricensis Rizzini ex Profice (Loranthaceae) (endemic to Brazil)

Asphondylia maricensis Maia \& Couri 1992

Eurytomidae, Platygaster sp. (Platygastridae)

Maia \& Couri 1992, Maia 2001b, Maia \& Azevedo 2009

Peplonia asteria (Vell.) Fontella \& E.A. Schwarz (Asclepiadaceae) (endemic to Atlantic Forest)

Asphondylia peploniae Maia 2001a

Eulophidae, Rileya sp. 1 (Eurytomidae), Torymidae

Maia 2001a, b, Maia \& Azevedo 2009

Guapira opposita (Vell.) Reitz (Nyctaginaceae) (native to Brazil)

Bruggmannia acaudata Maia 2004

Galeopsomyia sp. 1 (Eulophidae), Eupelmidae, Eurytoma sp. 9, Rileya sp. 3 (Eurytomidae), Torymidae

Maia 2001b, Maia 2004, Maia \& Azevedo 2009

Bruggmannia elongata Maia \& Couri 1993

Eupelmidae, Galeopsomyia sp. 1, Chrysotomyia sp., Cirrospilus sp. (Eulophidae), Rileya sp. 3, Eurytoma sp. 9 (Eurytomidae), Platygaster sp. (Platygastridae)

Maia \& Couri 1993, Maia 2001b, Maia \& Azevedo 2009

Bruggmannia robusta Maia \& Couri 1993

Eupelmidae, Galeopsomyia sp. 1, Chrysotomyia sp. (Eulophidae), Eurytoma sp., Rileya sp. 3 (Eurytomidae), Platygaster sp.

(Platygastridae)

Maia \& Couri 1993, Maia 2001b, Maia \& Azevedo 2009

Proasphondylia guapirae Maia 1994a

Eupelmidae, Rileya sp. 3, 5, 7 (Eurytomidae), Platygastridae

Maia 1994a, Maia 2001b, Maia \& Azevedo 2009

Byrsonima sericea DC. (Malpighiaceae) (native to Brazil)

Dasineura byrsonimae Maia 2010

Mymaridae, Eulophidae

Maia 2001b, Maia 2010, Maia \& Azevedo 2009

Monteverdia obtusifolia (Mart.) Biral (= Maytenus obtusifolia Mart.) (Celastraceae) (endemic to Brazil)

Mayteniella distincta Maia 2001a

Xanthellum sp. 1, Tetrastichinae (gen. nov.) (Eulophidae), Eupelmidae, Platygaster sp. (Platygastridae), Pteromalidae, Dimeromicrus cecidomyiae (Torymidae)

Maia2001a, Maia \& Azevedo 2009

Microstachys corniculata (Vahl) Griseb. (= Sebastiana glandulosa (Mart.) Pax.) (Euphorbiaceae) (native to Brazil)

Clinodiplosis conica Oliveira \& Maia 2008

Eulophidae

Maia 2001b, Oliveira \& Maia 2008, Maia \& Azevedo 2009

Paullinia weinmanniifolia Mart. (Sapindaceae) (endemic to Atlantic Forest)

Clinodiplosis costai Maia 2005

No parasitoids.

Maia 2005a

Paulliniamyia ampla Maia 2001

Braconidae, gen. nov. 2 sp. nov. 2, gen. nov. 5 sp. nov. 1, Aprostocetus sp. 1 (Eulophidae), Rileya sp. 8 (Eurytomidae), Eupelmidae, Leptacis sp. (Platygastridae), Dimeromicrus cecidomyiae (Torymidae)

Maia 2001a, b, Maia \& Azevedo 2009

Heteropterys nitida (Lam.) DC. (Malpighiaceae) (native to Brazil)

Clinodiplosis floricola Novo-Guedes \& Maia 2008

Aprostocetus sp. 1 (Eulophidae)

Maia 2001b, Novo-Guedes \& Maia 2008, Maia \& Azevedo 2009

Erythroxylum ovalifolium Peyr. (Erythroxylaceae) (endemic to Atlantic Forest)

Dasineura ovalifoliae Fernandes \& Maia 2011

Eupelmidae, Mymaridae, Pteromalidae, Torymidae, gen. nov. 6 sp. nov. 1 (Eulophidae), cecidophagous - Clinodiplosis maricaensis Fernandes \& Maia 2011

Maia 2001b, Fernandes \& Maia 2011, Maia \& Azevedo 2009

Lopesia erythroxyli Rodrigues \& Maia 2010

Eupelmidae, Eurytoma sp. 6 (Eurytomidae), Mymaridae, Pteromalidae, gen. nov. 6 sp. nov. 3 (Eulophidae)

Maia 2001b, Rodrigues \& Maia 2010, Maia \& Azevedo 2009

Eugenia uniflora L. (Myrtaceae) (native to Brazil)

Clinodiplosis profusa Maia 2001a

Chrysonotomyia sp., gen. nov. 2 sp. nov. 1, Aprostocetus sp. 1 (Eulophidae), Eupelmidae, Eurytoma sp. 8, Rileya sp. 3, 7 (Eurytomidae), Mymaridae, Platygastridae, Torymidae 
Refs.:

14) Host plant: Galler:

Parasitoids:

Refs.:

15) Host plant:

Galler:

Parasitoids:

Refs.:

Galler:

Parasitoids:

Refs.:

Galler:

Parasitoids:

Refs.:

16) Host plant:

Galler:

Parasitoids:

Refs.:

17) Host plant:

Galler:

Parasitoids:

Refs.:

18) Host plant:

Galler:

Parasitoids:

Refs.:

19) Host plant:

Galler:

Parasitoids:

Refs.:

20) Host plant:

Galler:

Parasitoids:

Refs.:

21) Host plant:

Galler:

Parasitoids:

Refs.:
Maia 2001a, Maia \& Azevedo 2009

Clusia lanceolata Cambess. (Clusiaceae) (endemic to Atlantic Forest)

Clusiamyia nitida Maia 1997

Encarsia sp. (Aphelinidae), Eulophidae, Eupelmidae, Eurytoma sp. 5 (Eurytomidae), Inostemma sp., Platygaster sp. (Platygastridae), Pteromalidae

Maia 1997, Maia 2001b, Maia \& Azevedo 2009

Eugenia astringens Cambess. (= Eugenia rotundifolia Casar) (Myrtaceae) (endemic to Atlantic Forest)

Dasineura globosa Maia 1996b

Eulophidae, Platygaster sp. (Platygastridae), Torymidae

Maia 1996b, Maia 2001b, Maia \& Azevedo 2009

Dasineura marginalis Maia 2005b

Closterocerus sp. 1, Pentastichus sp. 1, gen. nov. 6 sp. nov. 2, gen. nov. 4 sp. nov. 1 (Eulophidae), Torymidae

Maia 2001b, Maia 2005b, Maia \& Azevedo 2009

Stephomyia rotundifoliorum Maia 1994c

Donquickeia sp. (Braconidae), Eulophidae, Brasema sp. (Eupelmidae), Rileya sp. 5, Eurytoma sp. 7 (Eurytomidae), Platygastridae,

Dimeromicrus cecidomyiae (Torymidae)

Maia 1994c, Maia 2001b, Maia \& Azevedo 2009

Myrciaria floribunda (H. West ex Willd.) 0. Berg (Myrtaceae) (native to Brazil)

Dasineura myrciariae Maia 1996

Dimeromicrus cecidomyiae (Torymidae)

Maia 1996b, Maia 2001b, Maia \& Azevedo 2009

Pouteria venosa (Mart.) Baehni (Sapotaceae) (native to Brazil)

Lopesia singularis Maia 2001a

Tetrastichinae (gen. nov.) (Eulophidae), Eupelmidae, Eurytomidae, Platygastridae, Torymidae

Maia 2001a, b, Maia \& Azevedo 2009

Hylocereus setaceus (Salm-Dyck) R. Bauer (= Selenicereus setaceus (Salm-Dyck) Berg (Cactaceae) (native to Brazil)

Neolasioptera cerei (Rübsaamen 1905)

No parasitoids.

Rübsaamen 1905, Maia 2001b

Jacquemontia holosericea (Weinm.) 0'Donell (Convolvulaceae) (native to Brazil)

Schizomyia santosi Maia \& Araújo 2009

No parasitoids.

Maia 2001b, Maia \& Araújo 2009

Smilax rufescens Griseb. (Smilacaceae) (endemic to Brazil)

Smilasioptera candelariae Möhn 1975

Pentastichus sp. 3 (Eulophidae), Eupelmidae

Möhn 1975, Maia 2001b, Maia \& Azevedo 2009

Pouteria caimito (Ruiz \& Pav.) Radlk (= Pouteria caimito var. laurifolia) (Sapotaceae) (native to Brazil)

Youngomyia pouteriae Maia 2001c

Xanthobium sp. (Eulophidae), Eupelmidae, Platygastridae, Dimeromicrus cecidomyiae (Torymidae)

Maia 2001a, c, Maia \& Azevedo 2009

\section{REFERENCES}

Couri, M.S. \& Maia, V.C. 1992. Considerações sobre Pisphondylia Mohn, 1960 (Diptera, Cecidomyiidae, Asphondyliidi), com descrição de uma espécie nova do Brasil. Revista Brasileira de Entomologia, 37: 717-721.

Fernandes, S.P.C. \& Maia, V.C. 2011. Pp. 522-525. In: Maia, V.C. \& Fernandes, S.P.C. Two new species of gall midges (Diptera, Cecidomyiidae) associated with Erythroxylum ovalifolium Peyr. (Erythroxylaceae) from the Barra de Maricá restinga, Maricá, Rio de Janeiro, Brasil. Brazilian Journal of Biology, 71:521-526.

Maia, V.C. 1993. Descrição de duas espécies novas de Cecidomyiidae (Diptera) associadas a Eugenia spp. (Myrtaceae). Revista Brasileira de Entomologia, $37: 717-721$.

Maia, V.C. 1994a. Considerações sobre Proasphondylia Felt (Diptera, Cecidomyiidae), com descrições de duas espécies novas associadas com Guapira opposita (Velloso) Reitz (Nyctaginaceae). Revista Brasileira de Zoologia, 10: 215-218.

Maia, V.C. 1994b. Uma nova espécie de Clinodiplosis Kieffer (Diptera, Cecidomyiidae), associada com Melissa officinalis Linnaeus (Labiatae) no Brasil. Revista Brasileira de Zoologia, 10: 695-697.

Maia, V.C. 1994c. Considerações sobre Stephomyia Tavares (Diptera, Cecidomyiidae, Asphondyliidi), com descrição de quatro espécies novas associadas com Eugenia L. e Neomithranthes obscura (DC.) Legr. (Myrtaceae). Revista Brasileira de Zoologia, 10: 521-530.

Maia, V.C. 1995. Myrciariamyia bivalve, gen. n. e sp. n. (Diptera, Cecidomyiidae, Oligotrophini), associado com Myrciaria floribunda (Camb.) Legr. (Myrtaceae) no Brasil. Revista Brasileira de Zoologia, 11: 635-638.

Maia, V.C. 1996a. Cordiamyia globosa gen. n. e sp. n. (Diptera, Cecidomyiidae) associado com Cordia verbenacea DC. (Boraginaceae) no Brasil. Revista Brasileira de Zoologia, 13: 579-583. 
Maia, V.C. 1996b. Três espécies novas de Dasineura Rondani (Diptera, Cecidomyiidae) associadas a Myrtaceae, na restinga de Barra de Maricá, Rio de Janeiro. Revista Brasileira de Zoologia, 12: 1001-1008.

Maia, V.C. 1996c. Dois gêneros novos de Cecidomyiidae (Diptera) associados a Myrtaceae, na restinga de Barra de Maricá, Rio de Janeiro, Brasil. Revista Brasileira de Zoologia, 12: 567-574.

Maia, V.C. 1997. Clusiamyia nitida gen. n. e sp. n. (Diptera, Cecidomyiidae, Cecidomyiidi) associada com Clusia lanceolata Camb. (Clusiaceae) no Brasil. Revista Brasileira de Zoologia, 13: 829-832.

Maia, V.C. 2001a. New genera and species of gall midges (Diptera, Cecidomyiidae) from three restingas of Rio de Janeiro State, Brazil. Revista Brasileira de Zoologia, 18(Suppl. 1): 1-32.

Maia, V.C. 2001b. The gall midges (Diptera, Cecidomyiidae) from three restingas of Rio de Janeiro State, Brazil. Revista Brasileira de Zoologia, 18(2): 583-629.

Maia, V.C. 2001c. Two new species of gall midges (Diptera, Cecidomyiidae) associated with Pouteria caimito var. laurifolia (Sapotaceae) in Brazil. Studia Dipterologica, 8: $103-110$.

Maia, V.C. 2004. Description of a new species of Bruggmannia Tavares (Diptera, Cecidomyiidae) associated with Guapira opposita (Vell.) Reltz (Nyctaginaceae) in Brazil. Revista Brasileira de Zoologia, 21: 761-764.

Maia, V.C. 2005a. Clinodiplosis costai, a new galler species (Diptera, (ecidomyiidae) associated with Paullinia weinmanniaefolia Mart (Sapindaceae). Revista Brasileira de Zoologia, 22: 676-679.

Maia, V.C. 2005b. Pp. 348-352. In: Maia, V.C.; Constantino, P. de A.L. \& Monteiro, R.F. New gall midges (Diptera, Cecidomyiidae) associated with two species of Eugenia (Myrtaceae). Revista Brasileira de Entomologia, 49: 347-352.

Maia, V.C. 2010. A new species of Dasineura Rondani, 1840 (Diptera, Cecidomyiidae) associated with Byrsonima sericea (Malpighiaceae). Revista Brasileira de Biociências, 8(4): 337-380.

Maia, V.C. 2011. Pp. 41-43. In: Maia, V.C. \& Santos, J.C. A new genus and species of gall midge (Diptera, Cecidomyiidae) associated with Microgramma vaccinifolia (Langsd. \& Fisch.) Copel (Polypodiaceae) from Brazil. Revista Brasileira de Entomologia, 55: 40-44.

Maia, V.C. \& Araújo, W.S. de. 2009. Uma nova espécie de Schizomyia (Diptera, Cecidomyiidae) indutora de galhas nos botões florais de Jacquemontia holosericea (Convolvulaceae). Revista Brasileira de Entomologia, 53: 356-260.

Maia, V.C. \& Azevedo, M.A.P. de. 2009. Micro-himenópteros associados com galhas de Cecidomyiidae (Diptera) em Restingas do Estado do Rio de Janeiro (Brasil). Biota Neotropica, 9(2): 151-164.

Maia, V.C. \& Couri, M.S. 1992. Pp. 655-660. In: Maia, V.C., M.S. Couri, \& Monteiro, R.F. Sobre seis espécies de Asphondylia Loew, 1850 do Brasil (Diptera, (ecidomyiidae). Revista Brasileira de Entomologia, 36: 653-661.

Maia, V.C. \& Couri, M.S. 1993. Descrição de três espécies novas de Bruggmannia Tavares, 1906 (Diptera, Cecidomyiidae, Asphondyliidi) do Brasil associadas com Guapira opposita (Nyctaginaceae). Revista Brasileira de Biologia, 53: 209-215.

Maia, V.C. \& Nava, D.E. 2011. New gall midges (Diptera, Cecidomyiidae) associated with Eugenia uniflora and Psidium cattleianum (Myrtaceae). Iheringia, Série Zoologia, 101(1-2): 69-74.

Maia, V.C. \& Oliveira, U.P. de. 2007. Uma nova espécie de Cecidomyiidae (Diptera) associada com Sebastiania glandulosa (Euphorbiaceae). Iheringia, Série Zoologia, 97: 97-101.

Maia, V.C. \& Santos, M.G. 2015. Record of insects in two fern species of the genus Microgramma (Polypodiaceae) in the Atlantic Rain Forest, Rio de Janeiro state, Brazil. Brazilian Journal of Biology, 75(4), suppl. 1: S253-S254.

Möhn, E. 1959. Gallmucken (Diptera, Itonididae) aus El Salvador. 1. Teil. Senckenbergiana Biologica, 40: 297-368.

Möhn, E. 1975. Gallmucken (Diptera, Itonididae) aus El Salvador. 8. Teil. Lasiopteridi. Stuttgarter Beitrage zur Naturkunde, No. 276: 1-101.

Novo-Guedes, R. \& Maia, V.C. 2008. Gall midges (Diptera, Cecidomyiidae) associated with Heteropteris nitida (Malpigiaceae). Arquivos do Museu Nacional, 66: 359 -362.

Oliveira, U.P. de \& Maia, V.C. 2008. A new species of gall midge (Diptera, Cecidomyiidae) associated with Sebastiana glandulosa (Euphorbiaceae). Arquivos do Museu Nacional, Rio de Janeiro, 66: 355-358.

Rodrigues, A.R. \& Maia, V.C. 2010. Duas novas espécies de Lopesia Rubsaamen (Diptera, Cecidomyiidae) do Brasil, com chave para as espécies. Biota Neotropica, 10: 85-99.

Rübsaamen, E.H. 1905. Beitrage zur Kenntnis aussereuropaischer Zoocecidien. II. Beitrag: Gallen aus Brasilien und Peru. (Vorlaufige Mitteilung.) Marcellia 4: 65-85. Rübsaamen, E.H. 1908. Beitrage zur Kenntnis aussereuropaischer Zoocecidien. III. Beitrag: Gallen aus Brasilien und Peru. Marcellia 6: 110-173.

Sousa, L.I. de \& Maia, V.C. 2007. A new species of Schizomyia (Diptera, Cecidomyiidae, Asphondyliini) associated with Tetrapterys phlomoides (Malpighiaceae). Iheringia, Série Zoologia, 97: 311-313.

Viceconte, K.S. de M. \& Maia, V.C. 2009. Novo gênero e nova espécie de Diptera, Cecidomyiidae, associada com Psittacanthus dichrous (Loranthaceae). Arquivos do Museu Nacional, 67: 35-40. 